\title{
The Accumulation of Index Futures Basis Risk and Its Information Transmission Effect
}

\author{
Yuan $\mathrm{Li}^{1,2}$, Yanjun Xiang ${ }^{1,2}$ \\ ${ }^{1}$ School of Finance, Zhongnan University of Economics and Law, Wuhan, \\ 430073, China \\ ${ }^{2}$ Collaborative Innovation Center of Industrial Upgrading And Regional \\ Finance, Zhongnan University of Economics and Law, Wuhan 430073, \\ China
}

\begin{abstract}
Exploring the role of basis risk in the volatility spillover process of stock index futures has great significance to improving the trading mechanism and enhances the cross market risk management. By analyzing the basis risk clustering process with self-exciting process and discuss the relationship between basis risk and relative indexes with Granger causality tests, we explored the behavior characteristics of the basis risk in China's stock index futures market. The results show that there is a significant self-exciting process between CSI 300 future's basis risk clustering events. The clustered basis risk has significant impacts on the volatility of CSI 300, but its impacts on relative indexes are varied. The clustering of basis risk may not have the ability to cause an overall shock to the market.

Keywords:stock index futures, volatility spillover, information transmission, selfexciting process

\section{Introduction and literature review}

China's stock index futures market has become an important part of China's capital market in the recent five years. With the ups and downs of the stock index futures and spot market prices, especially sincethe stock market fluctuation in July 2015, the financial market order has been severely disrupted. The discussion about the stock index futures market volatility spill over to the risk problem in the
\end{abstract}


spot market, become the core of the market participants concerned again and academic research focus.

With the expansion of data access and mathematical analysis method in the field of financial research, scholars have gradually started to use high frequency data of numerical analysis of stock index futures spot price fluctuation; study time span gradually from the week data, daily data of Japanese trading in the time division data refinement, Stochastic Dominance Test (Qiao et al, 2013), Multifractal Detrended Cross-Correlation Analysis(Caoet al, 2014), VECM GARCH-M (Hou \& Li, 2014) and TVP-VAR (Zhou et al, 2014) were introduced research has been greatly enriched.

In short, the present study is lack of in-depth analysis on the volatility spill over problems from the perspective of basis risk. Compared with the existing literature, this paper work is done some useful exploration on the two aspects: one is starting from the basis point of view, analysis of the impact of the basis risk of volatility spill over effect of stock index futures market in China, to provide some new material for the research on the spill over problem of cross market; two is the process of forming the use of Hawkes self-point process description basis risk, make some experience on the accumulation characteristics better reflect the basis risk.

\section{Research methods}

The self-excitingprocess is used to describe the interaction among the accumulations of basis risk events to reflect the characteristics of the basis risk in the volatility and spillover process in stock index futures market.

\subsection{Model establishment}

Hawkes process is a kind of self-exciting characteristics of the point process, in its definition, occurrence of a specific type of event has a base frequency, once the specific events will occur, based on the frequency of subsequent events occurred jump, stimulation. In this paper, we obtain the following strength function:

$$
\lambda(t)=\mu+k \sum_{t_{k}<t} w e^{-w\left(t-t_{k}\right)}
$$

\subsection{Parameter estimation method in the self-exciting process}

Due to the high nonlinear characteristics, the optimization method can only be used to estimate the maximum likelihood estimation method. Therefore, the maximum likelihood estimation method is used to estimate the parameters. Specifically, its maximum likelihood function can be written in the following form:

$$
\log L\left(\mu, k, w \mid t_{1}, ., t_{n}\right)=\sum_{t_{i}: 2 \leq i \leq n} \log \left(\lambda\left(t_{i}\right)\right)-\int_{0}^{T} \lambda(t) d t
$$


The maximum likelihood function used to estimate is:

$$
\begin{aligned}
\log L\left(\mu, k, w \mid t_{1}, ., t_{n}\right)= & \sum_{t_{i}: 2 \leq i \leq n} \log \left(\mu+k \sum_{t_{k}<t} w e^{-w\left(t-t_{k}\right)}\right)-\mu T- \\
& k \sum_{t_{k}<t}\left(e^{w t_{k}}-e^{w\left(t_{k}-T\right)}\right)
\end{aligned}
$$

\section{Empirical analysis}

\subsection{Sample construction}

Hawkes self-strength function extraction of stock index futures, the Shanghai and Shenzhen 300 stock index futures contract data, data from Wind consulting financial terminal. The sample interval ranges from the April 16, 2010 to August 13, 2015. In order to calculate the Shanghai and Shenzhen 300 index earnings volatility corresponding to the stock index futures, we use the CSI 300 index daily data. The sample ranges from April 16, 2010 to August 13, 2015. Data is extracted from CSMAR financial database.

\subsection{Granger causality test of position data of stock index futures and basis}

Table 1 gives the Granger causality test of top twenty institutions of stock index futures and basis.

Table 1Granger causality test of position data of stock index futures and basis

\begin{tabular}{c|c|c|c|c|c|c|c}
\hline Variable & $\mathrm{x}$ & \multicolumn{2}{|c|}{ Overall basis } & \multicolumn{2}{c|}{$\begin{array}{c}\text { Basis in normal } \\
\text { situation }\end{array}$} & \multicolumn{2}{c}{$\begin{array}{c}\text { Basis in inverted } \\
\text { market }\end{array}$} \\
\hline $\mathrm{y}$ & $\begin{array}{c}\text { primary } \\
\text { hypothesis }\end{array}$ & F-test & $\begin{array}{c}\mathrm{P} \\
\text { Value }\end{array}$ & F-test & $\begin{array}{c}\mathrm{P} \\
\text { Value }\end{array}$ & F-test & $\begin{array}{c}\mathrm{P} \\
\text { Value }\end{array}$ \\
\hline
\end{tabular}

Sum of top 20 of position holders

\begin{tabular}{c|c|c|c|c|c|c|c}
\hline $\begin{array}{c}\text { Position of Stock } \\
\text { Index Futures of } \\
\text { CSI 300 }\end{array}$ & $\mathrm{y}<\neq \mathrm{x}$ & 22.6 & $\begin{array}{c}\text { Very } \\
\text { low }\end{array}$ & 16.42 & 0.0001 & 6.95 & 0.0089 \\
\cline { 2 - 8 } & $\mathrm{y} \neq>\mathrm{x}$ & 1.8 & 0.1799 & 3.87 & 0.0498 & 0.28 & 0.5996 \\
\hline
\end{tabular}

Securities company of the top 20 of position holders

\begin{tabular}{c|c|c|c|c|c|c|c}
\hline \multirow{2}{*}{$\mathrm{x}$} & $\mathrm{y}$ & \multicolumn{2}{|c|}{$\begin{array}{l}\text { Position of } \\
\text { Guotai Junan } \\
\text { Securities }\end{array}$} & \multicolumn{2}{|c|}{$\begin{array}{c}\text { Position of } \\
\text { Shenyin } \\
\text { Wanguo } \\
\text { Securities }\end{array}$} & $\begin{array}{r}\text { Position of } \\
\text { Zhongxin } \\
\text { Jiantou } \\
\text { Securities }\end{array}$ \\
\hline \multirow{2}{*}{ Overall basis } & $\mathrm{y}<\neq \mathrm{x}$ & 6.4 & 0.0116 & 0.02 & 0.8855 & 1.45 & 0.2295 \\
\cline { 2 - 8 } & $\mathrm{y} \neq>\mathrm{x}$ & 0.13 & 0.7197 & 7.31 & 0.007 & 0.17 & 0.6787 \\
\hline
\end{tabular}


From the Table 1, we can find that the basis has significant one-way causal relationship with the number of Shanghai and Shenzhen 300 index futures position in general, but under normal market conditions, both of which will be a two-way causal relationship. The relationship between the three agencies, the number of positions and the basis change is different. There is no causal relationship between consistencies. The result show the important influence on the basis on the stock index futures, but also reflects the relative independence of the basis changes in the relationship between stock index futures price in the amount, in addition to the influence degree of variation between the futures price and spot price basis.

\subsection{Features of self-exciting process of abnormal fluctuation of stock index futures}

The estimation results are listed in Table 2 on the basis risk accumulation events Hawkes self-process parameters. Different market conditions, parameters of $u$ all samples range from 0.1148 to 0.2123 . The parameter $u$ is 0.2123 overall basis risk accumulation, the accumulation of basic risk normal market conditions 0.1148 slightly lower than the market upside down 0.1185 . The $\mathrm{k}$ value fluctuated from 0.1077 to 0.1477 , the parameter $\mathrm{k}$ is 0.1477 overall basis risk accumulation. If we do not distinguish the basis risk event accumulation of market background, the response time is the overall accumulation of basis risk events for 18 days, which will occur once every three weeks of extreme events. In the normal market conditions, the response time between the accumulations of basis risk event is 37 days, 50 daysfaster than inverted market.

Table 2 Self-exciting process estimation of accumulation of index futures basis

\begin{tabular}{|c|c|c|c|c|c|c|c|}
\hline $\begin{array}{l}\text { Variabl } \\
\text { e name }\end{array}$ & $\mathrm{u}$ & $\mathrm{k}$ & $\mathrm{W}$ & $\begin{array}{l}\text { Respon } \\
\text { se time }\end{array}$ & $\begin{array}{l}\text { AIC } \\
\text { (yes) }\end{array}$ & $\begin{array}{l}\text { AIC } \\
(\text { no })\end{array}$ & $\begin{array}{c}\text { Event } \\
\mathrm{s} \\
\text { numb } \\
\text { er } \\
\end{array}$ \\
\hline $\begin{array}{c}\text { Overal } \\
1 \text { basis } \\
\text { risk }\end{array}$ & $\begin{array}{c}0.212 \\
3\end{array}$ & $\begin{array}{c}0.147 \\
7\end{array}$ & $\begin{array}{c}0.056 \\
7\end{array}$ & 18 & $\begin{array}{c}9.56 \mathrm{E}- \\
03\end{array}$ & $\begin{array}{c}1.13 \mathrm{E}+3 \\
01\end{array}$ & 539 \\
\hline $\begin{array}{l}\text { Basis } \\
\text { risk in } \\
\text { normal } \\
\text { market }\end{array}$ & $\begin{array}{c}0.114 \\
8\end{array}$ & $\begin{array}{c}0.107 \\
7\end{array}$ & $\begin{array}{c}0.026 \\
7\end{array}$ & 37 & $\begin{array}{c}- \\
1.21 \mathrm{E}+2 \\
1\end{array}$ & -1.1450 & 269 \\
\hline $\begin{array}{l}\text { Basis } \\
\text { risk in } \\
\text { inverte } \\
\mathrm{d} \\
\text { market }\end{array}$ & $\begin{array}{c}0.118 \\
5\end{array}$ & 0.119 & 0.02 & 50 & $\begin{array}{c}- \\
3.87 \mathrm{E}+1 \\
5\end{array}$ & -1.1481 & 270 \\
\hline
\end{tabular}




\subsection{Granger causality test of basis risk and index fluctuation}

The strength of the basis risk function basis risk overall strength function and normal market conditions, market conditions directly inverted by using BoxJenkins method. The overall strength of the basis risk function are given in Table 3.All the observation period, the function and the Shanghai and Shenzhen strength basis risk strength basis risk function, inverted and normal market conditions under the market conditions of the 300 index volatility Granger causality test results.

Table 3 Granger causality test

\begin{tabular}{|c|c|c|c|c|c|c|c|}
\hline \multirow{2}{*}{$\begin{array}{c}\text { Variable } \\
\text { y }\end{array}$} & \multirow{2}{*}{$\begin{array}{c}\mathrm{X} \\
\begin{array}{c}\text { primary } \\
\text { hypothesi } \\
\mathrm{S}\end{array}\end{array}$} & \multicolumn{2}{|c|}{$\begin{array}{l}\text { Overall } \\
\text { degree } \\
\text { function of } \\
\text { basis risk }\end{array}$} & \multicolumn{2}{|c|}{$\begin{array}{c}\text { Degree } \\
\text { function of } \\
\text { basis risk in } \\
\text { normal } \\
\text { situation }\end{array}$} & \multicolumn{2}{|c|}{$\begin{array}{c}\text { Degree } \\
\text { function of } \\
\text { basis risk in } \\
\text { inverted } \\
\text { Market }\end{array}$} \\
\hline & & $\begin{array}{l}\text { F- } \\
\text { test }\end{array}$ & $\begin{array}{c}\mathrm{P} \\
\text { value }\end{array}$ & $\begin{array}{l}\text { F- } \\
\text { test }\end{array}$ & $\begin{array}{c}\mathrm{P} \\
\text { Value }\end{array}$ & F-test & $\begin{array}{c}\mathrm{P} \\
\text { Value }\end{array}$ \\
\hline \multicolumn{8}{|c|}{ Index spot } \\
\hline \multirow{2}{*}{$\begin{array}{l}\text { Volatility of } \\
\text { CSI } 300\end{array}$} & $\mathrm{y}<\neq \mathrm{x}$ & 3.59 & $\begin{array}{c}0.058 \\
2\end{array}$ & 1.36 & $\begin{array}{c}0.243 \\
3\end{array}$ & 90.71 & $\begin{array}{l}\text { Very } \\
\text { low }\end{array}$ \\
\hline & $\mathrm{y} \neq>\mathrm{x}$ & 4.8 & $\begin{array}{c}0.028 \\
6\end{array}$ & 64.1 & $\begin{array}{l}\text { Very } \\
\text { low }\end{array}$ & $\begin{array}{c}227.4 \\
4\end{array}$ & $\begin{array}{l}\text { Very } \\
\text { low }\end{array}$ \\
\hline \multicolumn{8}{|c|}{ Connectivity index } \\
\hline \multirow{2}{*}{$\begin{array}{l}\text { Volatility of } \\
\text { Shanghai } \\
\text { stock } \\
\text { composite } \\
\text { index }\end{array}$} & $\mathrm{y}<\neq \mathrm{x}$ & 3.39 & $\begin{array}{c}0.065 \\
7 \\
\end{array}$ & 4.82 & $\begin{array}{c}0.028 \\
2 \\
\end{array}$ & 0 & $\begin{array}{c}0.978 \\
8 \\
\end{array}$ \\
\hline & $\mathrm{y} \neq>\mathrm{x}$ & 8.03 & $\begin{array}{c}0.004 \\
6\end{array}$ & 0.4 & $\begin{array}{c}0.525 \\
5\end{array}$ & 2.32 & $\begin{array}{c}0.127 \\
6\end{array}$ \\
\hline \multirow{2}{*}{$\begin{array}{l}\text { Volatility of } \\
\text { Shenzhen } \\
\text { compositio } \\
\text { n index }\end{array}$} & $\mathrm{y}<\neq \mathrm{x}$ & 1.45 & $\begin{array}{c}0.228 \\
6\end{array}$ & 0.04 & $\begin{array}{c}0.846 \\
9\end{array}$ & 0.05 & $\begin{array}{c}0.826 \\
2\end{array}$ \\
\hline & $\mathrm{y} \neq>\mathrm{x}$ & 0.81 & $\begin{array}{c}0.368 \\
6\end{array}$ & 3.46 & 0.063 & 0.45 & $\begin{array}{c}0.501 \\
8\end{array}$ \\
\hline \multirow{2}{*}{$\begin{array}{l}\text { Volatility of } \\
\text { small board } \\
\text { index }\end{array}$} & $\mathrm{y}<\neq \mathrm{x}$ & 0.23 & $\begin{array}{c}0.628 \\
9 \\
\end{array}$ & $\begin{array}{c}58.2 \\
9 \\
\end{array}$ & $\begin{array}{l}\text { Very } \\
\text { low }\end{array}$ & 2.96 & $\begin{array}{c}0.085 \\
6\end{array}$ \\
\hline & $\mathrm{y} \neq>\mathrm{x}$ & 0.56 & $\begin{array}{c}0.453 \\
5 \\
\end{array}$ & 0 & $\begin{array}{c}0.951 \\
2 \\
\end{array}$ & 2.99 & 0.084 \\
\hline \multirow{2}{*}{$\begin{array}{l}\text { Volatility of } \\
\text { GEM index }\end{array}$} & $\mathrm{y}<\neq \mathrm{x}$ & $\begin{array}{c}73.6 \\
1 \\
\end{array}$ & $\begin{array}{l}\text { Very } \\
\text { low }\end{array}$ & $\begin{array}{c}124 . \\
3\end{array}$ & $\begin{array}{l}\text { Very } \\
\text { low }\end{array}$ & 40.29 & $\begin{array}{l}\text { Very } \\
\text { low }\end{array}$ \\
\hline & $\mathrm{y} \neq>\mathrm{x}$ & 7.39 & $\begin{array}{c}0.006 \\
6\end{array}$ & 4.33 & $\begin{array}{c}0.037 \\
4\end{array}$ & 9.21 & $\begin{array}{c}0.002 \\
4\end{array}$ \\
\hline
\end{tabular}




\section{Conclusion and implications}

Based on the non-parametric Hawkes self-exciting process and Granger causality test, this paper studied the function of the basis risk in stock index futures market in the risk spill over process. The main conclusions are as follows: (1) the CSI 300 stock index futures and spot basis are the important factors to influence the behaviour of market. There are significantaccumulation characteristics of Hawkes self-exciting process. (2) From the perspective of the spot index of stock index futures basis risk return volatility and spot the obvious mutually affect each other. However, from the whole market perspective, there are some differences between the basis risk and main index change of income.

\section{References}

[1] Suo Y-Y, Wang D-H, Li S-P, Risk estimation of CSI 300 index spot and futures in China from a new perspective, Economic Modelling, (49), pp. 344-353, 2015.

[2] Ng V K, Pirrong S C, Fundamentals and Volatility: Storage, Spreads, and the Dynamics of Metals Prices, The Journal of Business, 67(2), pp. 203-230, 1994.

[3] Zhong M, Darrat A F, Otero R, Price discovery and volatility spillovers in index futures markets: Some evidence from Mexico, Journal of Banking \& Finance, 28(12), pp. 3037-3054, 2004.

[4] Qiao Z, Wong W-K, Fung J K W, Stochastic dominance relationships between stock and stock index futures markets: International evidence, Economic Modelling, (33), pp. 552-559, 2013.

[5] Cao G, Han Y, Cui W, et al, Multifractal detrended cross-correlations between the CSI 300 index futures and the spot markets based on high-frequency data, Physica A: Statistical Mechanics and its Applications, (414), pp. 308-320, 2014.

[6] Hou Y, Li S, The impact of the CSI 300 stock index futures: Positive feedback trading and autocorrelation of stock returns, International Review of Economics \& Finance, (33), pp. 319-337, 2014.

[7] Zhou Z, Dong H, Wang S, Intraday Volatility Spillovers between Index Futures and Spot Market: Evidence from China, Procedia Computer Science, (31), pp. 721-730, 2014.

[8]Hawkes A G, Spectra of some self-exciting and mutually exciting point processes, Biometrika, 58(1), pp. 83-90, 1971.

[9] Zhuang J, Ogata Y, Vere-Jones D, Stochastic declustering of space-time earthquake occurrences, Journal of the American Statistical Association, 97(458), pp. 369-380, 2002. 